\title{
Correction to: Activation of Co-Production: General Context and Antecedents
}

\section{CORRECTION TO:}

Chapter 3: D. Cepiku et al., The Co-production of Public Services, https:// doi.org/10.1007/978-3-030-60710-4_3

The book was inadvertently published without citing one of the coauthors. The corrections have now been carried out as follows:

In Chapter 3, Activation of Co-Production: General Context and Antecedents, Carmela Barbera is now listed as one of the co-authors.

The updated version of the chapter can be found at https://doi.org/10.1007/978-3-030-60710-4_3

(C) The Author(s) 2021

D. Cepiku et al., The Co-production of Public Services, https://doi.org/10.1007/978-3-030-60710-4_7 